\title{
Original Article \\ Risk factors for sexually transmitted diseases among women attending family planning clinics in Dar-es-Salaam, Tanzania
}

\author{
Dorota M Gertig, Saidi H Kapiga, John F Shao, David J Hunter
}

\begin{abstract}
Background: Identification of risk factors for sexually transmitted diseases (STDs) assists in development of treatment algorithms, which are potentially important components of STD control when microbiologic facilities are limited.

Methods: A cross-sectional study was performed to assess STD and HIV risk factors of 2285 women attending three family planning clinics in Dar-es-Salaam, Tanzania during 1991-92. Women were interviewed and examined for signs of STDs. Specimens were taken for laboratory diagnosis of HIV, other sexually transmitted organisms, and Candida albicans.

Results: The prevalence of gonorrhoea was found to be $4 \cdot 2 \%$, prevalence of trichomoniasis was $14.3 \%$, and positive syphilis serology was found in $2.5 \%$ of women. Unmarried women were at increased risk of trichomoniasis (age-adjusted OR $=1.4895 \%$ CI $[1.12,1.95]$ ), gonorrhoea (age-adjusted OR $=1.8195 \%$ CI $[1 \cdot 14,2 \cdot 86]$ ) and syphilis (age-adjusted OR $1 \cdot 5[0 \cdot 84,2 \cdot 68]$ ). An increasing number of sexual partners in the past five years was associated with an increased risk of all STDs. Current use of the oral contraceptive pill was positively associated with gonorrhoea, multivariate $\mathrm{OR}=1.7595 \% \mathrm{CI}[1.05,2 \cdot 93]$. The prevalence of candidiasis was $11.5 \%$ and was not associated with any of the demographic or behavioural risk factors examined. Clinical diagnostic algorithms for STDs in this study population had relatively low sensitivity and low positive predictive value.

Conclusion: Being unmarried and having a higher number of sexual partners were consistently associated with each STD, while the associations for other risk factors varied between STDs, emphasising the complexity of STD distribution. Further development of diagnostic algorithms and other methods for screening women for STDs are needed to reduce the impact of STDs and HIV in developing countries.

(Genitourin Med 1997;73:39-43)
\end{abstract}

Keywords: Sexually transmitted diseases; algorithms; risk factors

\section{Introduction}

Sexually transmitted diseases (STDs) are an important public health problem in Africa. Studies have shown a high prevalence of STDs in many African countries, even among women thought to be at low risk of acquiring STDs. ${ }^{1-4}$ The highest prevalence of STDs is usually reported from studies of female prostitutes; however, pregnant women, women attending family planning clinics and women in the general population have also been shown to bear a significant burden of STDs. ${ }^{15}$

In addition to the substantial complications which may result from STD infection when untreated, including infertility, pelvic inflammatory disease, and neonatal pathology, STDs have been shown to influence HIV transmission. ${ }^{6-8}$ The presence of STD may enhance HIV transmission, and the immunodeficiency associated with HIV infection may alter the natural history, diagnosis or response to therapy of STD. ${ }^{910}$

Despite the extent of the STD problem, and its contribution to the rapid spread of the HIV epidemic, relatively few studies have been performed of STD risk factors among women in Africa thought to be at low risk. Identification of risk factors for STDs may enable more appropriate targeting of the limited resources available for diagnosis and treatment of STDs, and may aid in the development of improved algorithms for STD treatment. To examine the behavioural and biological risk factors for STDs and candidiasis among low risk women, we analysed data from a large cross sectional study which was conducted primarily to examine HIV risk factors, in particular contraceptive use, among women in family planning clinics in Dar-es-Salaam, Tanzania. In addition, we evaluated the performance of key STD risk factors in diagnostic algorithms.

\section{Methods}

i. Study design

This study utilised a cross-sectional case control design, and details of data collection and methods have been described elsewhere. ${ }^{11}$ In brief, women attending three family planning clinics in urban areas of Dar-es-Salaam, between February 1991 and June 1992, were invited to participate in the study. Women who were new and continuing contraceptive users were enrolled after informed consent was obtained. Women were interviewed by trained female interviewers regarding sociodemographic characteristics, type of contraceptive use, sexual history and other potential risk factors for HIV/STD. A small validation study of contraceptive use was performed and good correlation was found $(r>0 \cdot 8)$ between selfreported use and medical records. ${ }^{11}$ Physical 
examination was performed, which included taking genital swabs; however 254 women were not examined because they had their menstrual period at the time of examination and did not return for a subsequent appointment. Blood was collected for syphilis and HIV-1 serology. The study protocol was approved by ethics committees of the Muhimbili Medical Centre and the National AIDS Control Programme.

\section{ii. Laboratory methods}

Active syphilis was diagnosed if subjects were positive on both the VDRL test (Murex Diagnostic, Dartford, England) and Treponema Pallidum Hemagglutination (TPHA: Fujirebio, Tokyo, Japan). Specimens from the endocervix and posterior fornix were placed in transport media, transported to the laboratory on the same day, then inoculated onto Thayer Martin media and incubated at $34-36^{\circ} \mathrm{C}$ for $48 \mathrm{~h}$. Isolation of gram-negative diplococci and positive oxidase and sugar fermentation reactions were used to detect the presence of Neisseria gonorrhoeae. Trichomonas vaginalis was diagnosed by visualisation of the organism on wet preparation. Blood specimens were tested for HIV-1 ELISA (Wellcome Recombinant HIV-1, Wellcome Diagnostics, Research Triangle Park, NC, USA) and were considered positive only when confirmed by Western Blot (Dupont de Nemours, Wilmington, DE, USA). Candida albicans was detected by isolation of gram neg- ative yeast-like cells on Saboraud's dextrose agar.

\section{iii. Statistical methods}

Stratified analyses were performed for all STDs and candidiasis, to assess potential confounding and effect modification. SPSS software was used for all analyses. ${ }^{12}$ Multivariate logistic regression, with separate models for each STD and candidiasis, was performed to control for potentially confounding factors. Confidence intervals were calculated based on coefficients and standard errors from the logis- $\stackrel{0}{\longrightarrow}$ tic model $^{13}$ and approximate confidence intervals were calculated for binomial proportions. ${ }^{14}$ Variables were entered into the model based on level of significance in univariate analyses $(p<0.25)$ and further variables of के interest were entered into the model based $\overrightarrow{0}$ upon prior knowledge of STD risk factors and to ensure comparability of risk factors for all

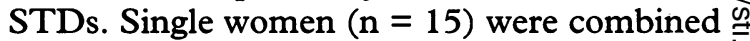
with cohabiting women $(n=637)$ for the analysis. Sensitivity, specificity and positive predictive value (PPV) of various predictor variables and clinical signs were calculated for $\stackrel{\circ}{2}$ each STD. We also evaluated the performance of the diagnostic algorithm proposed by $\frac{\pi}{71}$ Vuylsteke $e t a l^{15}$ in our study population. Each woman was assigned a score based on variables from the Vuylsteke algorithm that were available in our study: single/cohabiting $=5,8$ $\geqslant 2$ sexual partners in the past 5 years $=10$, $<25$ years $=14,25-29$ years $=11$, history of

Table 1 Risk factors for gonorrhoea, trichomoniasis and syphilis among women in family planning clinics, Dar-es-Salaam, Tanzania, 1991-1992

\begin{tabular}{|c|c|c|c|c|c|c|c|c|c|c|c|}
\hline \multirow[b]{2}{*}{ Predictor } & \multicolumn{4}{|c|}{ Gonorrhoea } & \multicolumn{3}{|c|}{ Trichomoniasis } & \multicolumn{4}{|c|}{ Syphilis } \\
\hline & $N^{*}$ & $\begin{array}{l}\% \\
+v e\end{array}$ & $\begin{array}{l}\text { Age adjusted } \\
\text { OR }[95 \% \text { CI] }\end{array}$ & $\begin{array}{l}\text { ORt } \\
{[95 \% \text { CI] }}\end{array}$ & $\begin{array}{l}\% \\
+v e\end{array}$ & $\begin{array}{l}\text { Age adjusted } \\
\text { OR [95\% CI] }\end{array}$ & $\begin{array}{l}\text { ORt } \\
{[95 \% \mathrm{CI}]}\end{array}$ & $N$ & $\begin{array}{l}\% \\
+v e\end{array}$ & $\begin{array}{l}\text { Age adjusted } \\
\text { OR [95\% CI] }\end{array}$ & $\begin{array}{l}\text { ORt } \\
{[95 \% \mathrm{CI}]}\end{array}$ \\
\hline $\begin{array}{l}\text { Marital status: } \\
\text { Married } \\
\text { (monogamous) } \\
\text { Married }\end{array}$ & 1336 & $(3 \cdot 4)$ & $1 \cdot 0 \ddagger$ & $1 \cdot 0$ & $(12 \cdot 0)$ & $1 \cdot 0 \ddagger$ & $1 \cdot 0 \ddagger$ & 1485 & $(2 \cdot 1)$ & $1 \cdot 0$ & $1 \cdot 0$ \\
\hline $\begin{array}{l}\text { (polygamous) } \\
\text { Unmarried }\end{array}$ & $\begin{array}{l}126 \\
569\end{array}$ & $\begin{array}{l}(4 \cdot 0) \\
(6 \cdot 2)\end{array}$ & $\begin{array}{l}1 \cdot 23[0 \cdot 48,3 \cdot 17] \\
1 \cdot 81[1 \cdot 14,2 \cdot 86]\end{array}$ & $\begin{array}{l}1.36[0.51,3.64] \\
1.55[0.92,2.61]\end{array}$ & $\begin{array}{l}(26 \cdot 2) \\
(17 \cdot 0)\end{array}$ & $\begin{array}{l}2 \cdot 65[1 \cdot 72,4 \cdot 08] \\
1 \cdot 48[1 \cdot 12,1 \cdot 95]\end{array}$ & $\begin{array}{l}2 \cdot 27[1 \cdot 43,3 \cdot 61] \\
1 \cdot 44[1.05,2 \cdot 00]\end{array}$ & $\begin{array}{l}148 \\
652\end{array}$ & $\begin{array}{l}(3 \cdot 4) \\
(3 \cdot 1)\end{array}$ & $\begin{array}{l}1.69[0.64,4.43] \\
1.50[0.84,2.68]\end{array}$ & $\begin{array}{l}1.93[0.68,5.46] \\
1.10[0.57,2.09]\end{array}$ \\
\hline $\begin{array}{l}\text { Education: } \\
\text { None/adult } \\
\text { Primary (1-4 yrs) } \\
\text { Primary 5-7 yrs) } \\
\text { Secondary }\end{array}$ & $\begin{array}{r}233 \\
212 \\
1479 \\
107\end{array}$ & $\begin{array}{l}(2 \cdot 1) \\
(6 \cdot 6) \\
(4 \cdot 3) \\
(3 \cdot 7)\end{array}$ & $\begin{array}{l}1 \cdot 0 \\
2.94[1 \cdot 03,8 \cdot 37] \\
1.61[0.62,4 \cdot 20] \\
1.42[0.37,5.54]\end{array}$ & $\begin{array}{l}1 \cdot 0 \\
3.46[1 \cdot 17,10 \cdot 28] \\
1 \cdot 83[0 \cdot 67,5 \cdot 00] \\
1.53[0 \cdot 34,6 \cdot 88]\end{array}$ & $\begin{array}{r}(15 \cdot 0) \\
(17 \cdot 5) \\
(14 \cdot 3) \\
(6 \cdot 5)\end{array}$ & $\begin{array}{l}1 \cdot 0 \ddagger \\
1 \cdot 17[0.70,1.95] \\
0.86[0.57,1.31] \\
0.36[0.15,0.85]\end{array}$ & $\begin{array}{l}1.0 \\
1.37[0.80,2.35] \\
1.04[0.66,1.63] \\
0.35[0.13,0.91]\end{array}$ & $\begin{array}{r}264 \\
232 \\
1661 \\
128\end{array}$ & $\begin{array}{l}(3 \cdot 8) \\
(2 \cdot 6) \\
(2 \cdot 3) \\
(0 \cdot 8)\end{array}$ & $\begin{array}{l}1.0 \\
0.63[0.22,1 \cdot 77] \\
0.54[0.25,1 \cdot 17] \\
0 \cdot 18[0.02,1.44]\end{array}$ & $\begin{array}{l}1.0 \\
0.66[0.22,1.95] \\
0.64[0.28,1.47] \\
0.25[0.03,2.31]\end{array}$ \\
\hline $\begin{array}{l}\text { Occupation: } \\
\text { Housewife } \\
\text { Agricultural/ }\end{array}$ & 1090 & $(4 \cdot 2)$ & $1 \cdot 0$ & $1 \cdot 0$ & $(13 \cdot 9)$ & $1 \cdot 0$ & $1 \cdot 0$ & 1226 & $(2 \cdot 0)$ & $1 \cdot 0$ & $1 \cdot 0$ \\
\hline $\begin{array}{l}\quad \text { manual } \\
\text { Small scale trader } \\
\text { Hotel worker } \\
\text { Secretar'l/ }\end{array}$ & $\begin{array}{r}106 \\
698 \\
19\end{array}$ & $\begin{array}{l}(4 \cdot 7) \\
(4 \cdot 0) \\
(5 \cdot 3)\end{array}$ & $\begin{array}{l}1 \cdot 15[0.45,3.00] \\
1.00[0.61,1.62] \\
1.22[0.16,9.38]\end{array}$ & $\begin{array}{l}0.97[0.37,2.57] \\
0.89[0.54,1.48] \\
1.15[0.13,9.54]\end{array}$ & $\begin{array}{r}(11 \cdot 3) \\
(15 \cdot 3) \\
(5 \cdot 3)\end{array}$ & $\begin{array}{l}0.80[0.43,1.49] \\
1.15[0.88,1.52] \\
0.35[0.05,2.66]\end{array}$ & $\begin{array}{l}0.73[0.38,1.41] \\
1.03[0.77,1.37] \\
0.24[0.03,1.89]\end{array}$ & $\begin{array}{r}123 \\
778 \\
21\end{array}$ & $\begin{array}{l}(3 \cdot 3) \\
(2 \cdot 8) \\
-\end{array}$ & $\begin{array}{l}1.67[0.57,4.90] \\
1.43[0.79,2.57] \\
-\end{array}$ & $\begin{array}{l}1.68[0.54,5 \cdot 26] \\
1.32[0.71,2 \cdot 44] \\
-\quad-\end{array}$ \\
\hline $\begin{array}{l}\text { profess'nl } \\
\text { Other }\end{array}$ & $\begin{array}{l}55 \\
63\end{array}$ & $\begin{array}{l}(3 \cdot 6) \\
(6 \cdot 3)\end{array}$ & $\begin{array}{l}0.91[0.21,3.87] \\
1.57[0.54,4.51]\end{array}$ & $\begin{array}{l}0.93[0.19,4 \cdot 70] \\
1.32[0.43,4.03]\end{array}$ & $\begin{array}{l}(14 \cdot 5) \\
(17 \cdot 5)\end{array}$ & $\begin{array}{l}1 \cdot 13[0 \cdot 52,2 \cdot 46] \\
1 \cdot 30[0.66,2 \cdot 55]\end{array}$ & $\begin{array}{l}1.48[0.61,3.61] \\
1.03[0.50,2.13]\end{array}$ & $\begin{array}{l}69 \\
68\end{array}$ & $\begin{array}{l}(1 \cdot 4) \\
(5 \cdot 9)\end{array}$ & $\begin{array}{l}0.69[0 \cdot 09,5 \cdot 21] \\
3 \cdot 19[1 \cdot 07,9 \cdot 49]\end{array}$ & $\begin{array}{l}1.30[0.15,11.41] \\
3.37[1.04,10.91]\end{array}$ \\
\hline $\begin{array}{l}\text { Sex partners last } 5 \\
1 \\
2 \\
3 \\
4+\end{array}$ & $\begin{array}{l}\text { yrs: } \\
1094 \\
524 \\
228 \\
185\end{array}$ & $\begin{array}{l}(3 \cdot 1) \\
(5 \cdot 3) \\
(6 \cdot 6) \\
(4 \cdot 9)\end{array}$ & $\begin{array}{l}1 \cdot 0 \\
1 \cdot 74[0 \cdot 91,2 \cdot 56] \\
2 \cdot 13[1 \cdot 14,4 \cdot 01] \\
1 \cdot 55[0 \cdot 73,3 \cdot 30]\end{array}$ & $\begin{array}{l}1 \cdot 0 \\
1 \cdot 53[0 \cdot 89,2 \cdot 64] \\
1 \cdot 79[0 \cdot 90,3 \cdot 55] \\
1 \cdot 25[0 \cdot 55,2 \cdot 85]\end{array}$ & $\begin{array}{l}(11 \cdot 8) \\
(17 \cdot 7) \\
(19 \cdot 3) \\
(13 \cdot 0)\end{array}$ & $\begin{array}{l}1 \cdot 0 \ddagger \\
1 \cdot 58[1 \cdot 18,2 \cdot 11] \\
1 \cdot 76[1 \cdot 21,2 \cdot 57] \\
1 \cdot 10[0 \cdot 69,1 \cdot 76]\end{array}$ & $\begin{array}{l}1.0 \\
1.36[1.00,1.86] \\
1.50[1.00,2 \cdot 26] \\
1.01[0.61,1.69]\end{array}$ & $\begin{array}{r}1213 \\
603 \\
259 \\
210\end{array}$ & $\begin{array}{l}(1 \cdot 8) \\
(2 \cdot 7) \\
(4 \cdot 2) \\
(3 \cdot 3)\end{array}$ & $\begin{array}{l}1 \cdot 0 \ddagger \\
1 \cdot 54[0 \cdot 80,2 \cdot 97] \\
2 \cdot 46[1 \cdot 18,5 \cdot 16] \\
1 \cdot 87[0 \cdot 79,4 \cdot 46]\end{array}$ & $\begin{array}{l}1 \cdot 0 \\
1.35[0.68,2.69] \\
2 \cdot 26[1.02,4.97] \\
1 \cdot 74[0.67,4.53]\end{array}$ \\
\hline $\begin{array}{l}\text { Age first intercours } \\
9-15 \mathrm{yrs} \\
16-17 \mathrm{yrs} \\
18-19 \mathrm{yrs} \\
>20 \mathrm{yrs}\end{array}$ & $\begin{array}{l}\text { se: } \\
560 \\
830 \\
447 \\
194\end{array}$ & $\begin{array}{l}(4 \cdot 1) \\
(3 \cdot 6) \\
(6 \cdot 3) \\
(2 \cdot 6)\end{array}$ & $\begin{array}{l}1.0 \\
0.87[0.50,1.51] \\
1.51[0.84,2.68] \\
0.61[0.23,1.65]\end{array}$ & $\begin{array}{l}1.0 \\
0.94[0.52,1.67] \\
1.92[1.04,3.55] \\
0.79[0.28,2.25]\end{array}$ & $\begin{array}{l}(16 \cdot 6) \\
(14 \cdot 5) \\
(12 \cdot 5) \\
(10 \cdot 8)\end{array}$ & $\begin{array}{l}1.0 \ddagger \\
0.83[0.62,1.12] \\
0.71[0.49,1.02] \\
0.63[0.38,1.05]\end{array}$ & $\begin{array}{l}1.0 \\
0.89[0.65,1.21] \\
0.87[0.59,1.27] \\
0.79[0.46,1.37]\end{array}$ & $\begin{array}{l}633 \\
935 \\
494 \\
223\end{array}$ & $\begin{array}{l}(3 \cdot 2) \\
(2 \cdot 6) \\
(1 \cdot 8) \\
(1 \cdot 3)\end{array}$ & $\begin{array}{l}1 \cdot 0 \\
0.83[0.45,1.51] \\
0.56[0.25,1.26] \\
0.40[0.11,1.36]\end{array}$ & $\begin{array}{l}1 \cdot 0 \\
0 \cdot 80[0.42,1.50] \\
0 \cdot 59[0 \cdot 25,1.36] \\
0 \cdot 43[0 \cdot 12,1.56]\end{array}$ \\
\hline $\begin{array}{l}\text { Current OC use: } \\
\text { No } \\
\text { Yes }\end{array}$ & $\begin{array}{r}864 \\
1167\end{array}$ & $\begin{array}{l}(2 \cdot 8) \\
(5 \cdot 3)\end{array}$ & $\begin{array}{l}1 \cdot 0 \\
1 \cdot 94[1 \cdot 20,3 \cdot 14]\end{array}$ & $\begin{array}{l}1 \cdot 0 \\
1 \cdot 75[1 \cdot 05,2 \cdot 93]\end{array}$ & $\begin{array}{l}(17 \cdot 4) \\
(12 \cdot 0)\end{array}$ & $\begin{array}{l}1.0 \\
0.65[0.51,0.84]\end{array}$ & $\begin{array}{l}1.0 \\
0.71[0.54,0.94]\end{array}$ & $\begin{array}{r}978 \\
1307\end{array}$ & $\begin{array}{l}(2 \cdot 6) \\
(2 \cdot 4)\end{array}$ & $\begin{array}{l}1.0 \\
0.92[0.54,1.58]\end{array}$ & $\begin{array}{l}1.0 \\
0.96[0.53,1.73]\end{array}$ \\
\hline $\begin{array}{l}\text { Condom use: } \\
\text { Never } \\
\text { Sometimes } \\
\text { Always }\end{array}$ & $\begin{array}{r}1525 \\
408 \\
98\end{array}$ & $\begin{array}{l}(4 \cdot 3) \\
(4 \cdot 4) \\
(2 \cdot 0)\end{array}$ & $\begin{array}{l}1.0 \\
0.97[0.57,1.66] \\
0.43[0.10,1.79]\end{array}$ & $\begin{array}{l}1 \cdot 0 \\
1.02[0.57,1.79] \\
0.46[0.11,1.94]\end{array}$ & $\begin{array}{l}(15 \cdot 4) \\
(10 \cdot 3) \\
(13 \cdot 3)\end{array}$ & $\begin{array}{l}1.0 \neq \\
0.61[0.43,0.86) \\
0.83[0.45,1.50]\end{array}$ & $\begin{array}{l}1.0 \\
0.71[0.49,1.03] \\
0.94[0.50,1.75]\end{array}$ & $\begin{array}{r}1726 \\
453 \\
106\end{array}$ & $\begin{array}{l}(2 \cdot 7) \\
(2 \cdot 0) \\
(0 \cdot 9)\end{array}$ & $\begin{array}{l}1.0 \\
0.74[0.36,1.53] \\
0.35[0.05,2.53]\end{array}$ & $\begin{array}{l}1.0 \\
0.75[0.35,1.62] \\
0.31[0.04,2.35]\end{array}$ \\
\hline
\end{tabular}

^Specimens were unavailable for 254 women.

†From a model including: number of sex partners in past five years, marital status, education, age, occupation, husband's occupation, husband's education, clinic, age at first intercourse, contraceptive use, history of treatment for STD in past year, HIV status.

$\neq$ Test for trend, $p<0.05$ 
discharge $=1$, pelvic pain $=3$, vaginal discharge $=4, \quad$ cervical discharge $=17$. The scores were then compared with laboratory results to determine performance of the algorithm. Cut-offs were varied to maximise sensitivity and specificity.

\section{Results}

The prevalence of sexually transmitted diseases among the 2285 women examined was: $4 \cdot 2 \%(86 / 2031) 95 \%$ CI $[3 \cdot 3,5 \cdot 7]$ for gonorrhoea, $14 \cdot 3 \%(290 / 2031) 95 \%$ CI $[12 \cdot 8,15 \cdot 8]$ for trichomoniasis and $2.5 \%(56 / 2285) \quad 95 \%$ CI $[1.8,3.2]$ for syphilis. The prevalence of candidiasis was $11.5 \%(234 / 2031) 95 \%$ CI $[10 \cdot 1,12.9]$. HIV prevalence in this population has previously been reported as $11.5 \% .^{11}$

The women ranged in age between 15-48 years (median 25.5); age was not consistently a significant risk factor for any of the STDs (data not shown). Most women (65\%) were in a monogamous marriage; and when compared with these, married polygamous women were at increased risk of syphilis, age-adjusted OR $=1.6995 \% \mathrm{CI}[0.64,4.43]$ and trichomoniasis, age-adjusted $\mathrm{OR}=2.6595 \% \mathrm{CI}[1.72$, $4 \cdot 08$ ]. Unmarried women were at approximately $50 \%$ increased risk for gonorrhoea and trichomoniasis, age-adjusted $\mathrm{OR}=1.8195 \%$ CI $[1 \cdot 14,2 \cdot 86]$, age-adjusted OR $=1.4895 \%$ CI $[1.12,1.95]$ respectively, but there was no significant association with syphilis, table 1 .

Secondary education was inversely associated with trichomoniasis $(\sim 65 \%$ decreased risk) and syphilis ( $75 \%$ decreased risk) with borderline significant decreasing trends in the age-adjusted analyses (table 1 ). Nearly $50 \%$ of women in the study were housewives and no clear associations emerged with the woman's occupation and STDs. In addition, there was no consistent association with husband's occupation or education (data not shown).

Increasing number of sex partners in the past five years was associated with an

Table 2 Sensitivity, specificity and positive predictive value of selected predictors of STDs

\begin{tabular}{|c|c|c|c|c|}
\hline Predictor variables & $N^{*}$ & $\begin{array}{l}\text { Sensitivity } \\
(\%)\end{array}$ & $\begin{array}{l}\text { Specificity } \\
(\%)\end{array}$ & $\begin{array}{l}P P V t \\
(\%)\end{array}$ \\
\hline \multicolumn{5}{|l|}{ Gonorrhoea } \\
\hline Unmarried & 652 & 41 & 73 & 6 \\
\hline$>2$ sex partners in past 5 years & 469 & 28 & 80 & 6 \\
\hline Vaginal/cervical discharge & 758 & 51 & 63 & 6 \\
\hline \multicolumn{5}{|l|}{ Unmarried or $>2$ sex partners in } \\
\hline \multirow{3}{*}{$\begin{array}{l}\text { past } 5 \text { years or vaginal/cervical discharge } \\
\text { Unmarried and }>2 \text { sex partners in } \\
\text { past } 5 \text { years and vaginal/cervical discharge }\end{array}$} & 1202 & 76 & 42 & 5 \\
\hline & & & & \\
\hline & 90 & 6 & 96 & 6 \\
\hline \multicolumn{5}{|l|}{ Trichomoniasis } \\
\hline Unmarried & 652 & 33 & 73 & 17 \\
\hline$>2$ sex partners in past 5 years & 469 & 23 & 80 & 17 \\
\hline Vaginal/cervical discharge & 758 & 46 & 64 & 18 \\
\hline \multicolumn{5}{|l|}{ Unmarried or $>2$ sex partners in } \\
\hline past 5 years or vaginal/cervical discharge & 1202 & 66 & 42 & 16 \\
\hline \multirow{2}{*}{$\begin{array}{l}\text { Unmarried and }>2 \text { sex partners in } \\
\text { past } 5 \text { years and vaginal/cervical discharge }\end{array}$} & & & & \\
\hline & 90 & 7 & 96 & 21 \\
\hline \multicolumn{5}{|l|}{ Syphilis serology } \\
\hline Unmarried & 652 & 36 & 72 & 3 \\
\hline$>2$ sex partners in past 5 years & 469 & 32 & 80 & 4 \\
\hline Vulval ulcers & 5 & 0 & 99 & 0 \\
\hline \multicolumn{5}{|l|}{$\begin{array}{l}\text { Unmarried or }>2 \text { sex partners in } \\
\text { past } 5 \text { years or vulval ulcers }\end{array}$} \\
\hline \multirow[b]{2}{*}{$\begin{array}{l}\text { Unmarried and }>2 \text { sex partners in } \\
\text { past } 5 \text { years and vulval ulcers }\end{array}$} & 884 & 48 & 62 & 4 \\
\hline & 0 & 0 & 100 & 0 \\
\hline
\end{tabular}

* Total number of women with each risk factor or combination of risk factors. †Positive predictive value. increased risk for all STDs; however, the tests for trend were only significant in the ageadjusted analyses, table 1 . Older age at first sexual intercourse (more than 20 years) was inversely associated with trichomoniasis, syphilis and gonorrhoea.

Current use of oral contraceptives (OC) was significantly positively associated with gonorrhoea, multivariate $\mathrm{OR}=1.7595 \% \mathrm{CI}$ $[1.05,2.93]$, but inversely associated with trichomoniasis, multivariate $\mathrm{OR}=0.7195 \% \mathrm{CI}$ [0.54, 0.94] (table 1). Use of the intrauterine device was non-significantly positively associated with both trichomoniasis, multivariate OR $1.69[0.90,3.19]$ and syphilis, multivariate OR $1.91[0.52,7 \cdot 10]$. Condom use was very low even in this population of women using family planning; only $4.6 \%$ of women reported regular condom use and $20 \%$ reported infrequent condom use. There were inverse associations between regular condom use and gonorrhoea and syphilis, after controlling for other risk factors, although none of the odds ratios reached statistical significance.

Candidiasis was not significantly associated with any of the risk factors examined in table 1. Unlike the STDs examined, candidiasis was not associated with being unmarried, ageadjusted OR $1.08[0 \cdot 80,1 \cdot 47]$ or with number of sex partners in the last 5 years (test for trend $p=0.69)$.

Almost a quarter of the women $(23.9 \%)$ reported potentially STD related symptoms, including vaginal discharge, lower abdominal pain, painful intercourse and malodorous discharge. Cervical discharge was present in nearly $16 \%$ of women on examination, although only $7 \cdot 2 \%$ reported symptoms of vaginal discharge. The prevalence of vulval or vaginal ulcers on examination was very low $(0 \cdot 3 \%)$. The presence of cervical discharge on examination was predictive of both gonorrhoea (age-adjusted OR $=1.7895 \% \mathrm{CI}[0.34$, $0.94]$ ) and trichomoniasis (age-adjusted OR = $2 \cdot 2595 \%$ CI $[1 \cdot 66,3 \cdot 04]$.

Several associations were observed between STDs. HIV was associated with an almost twofold increased risk of gonorrhoea and $30-50 \%$ increased risk of candida and syphilis. ${ }^{11}$ Gonorrhoea and syphilis were positively associated, multivariate $\mathrm{OR}=1.6595 \%$ CI $[0.54,5.05]$ after controlling for other risk factors, and gonorrhoea was inversely associated with the presence of candidiasis, multivariate $\mathrm{OR}=0.3395 \% \mathrm{CI}[0 \cdot 12,0.93]$.

Sensitivity, specificity and positive predictive values for selected risk factors, symptoms and signs, both individually and in combination, are presented in table 2 . Sensitivity of the combined variables (being unmarried or having greater than two sexual partners in the past 5 years or the presence of vaginal/cervical discharge on examination) was acceptable for gonorrhoea and trichomoniasis, however, specificity was low $(42 \%)$. The performance of the algorithm for gonorrhoea derived by Vuylsteke et $a l,{ }^{15}$ using only the variables that we had collected in our study and with no microbiological diagnosis of chlamydia, is shown in table 3 . Using a cut-off of 28 , as for 
Table 3 Sensitivity, specificity and positive predictive of diagnostic algorithm (Vuylsteke et al) ${ }^{15}$ for gonorrhoea with varying cut-off points

\begin{tabular}{llll}
\hline $\begin{array}{l}\text { History and } \\
\text { examination variables }\end{array}$ & Sensitivity & Specificity & $P P V^{\star}$ \\
\hline Cut-off $>8$ & $98 \%$ & $15 \%$ & $5 \%$ \\
Cut-off $>13$ & $80 \%$ & $30 \%$ & $5 \%$ \\
Cut-off $>20$ & $58 \%$ & $56 \%$ & $6 \%$ \\
Cut-off $>28$ & $38 \%$ & $76 \%$ & $7 \%$ \\
& & & \\
History variables only & Sensitivity & Specificity & $P P V^{\star}$ \\
Cut-off $>8$ & $97 \%$ & $17 \%$ & $5 \%$ \\
Cut-off $>13$ & $72 \%$ & $37 \%$ & $5 \%$ \\
Cut-off $>20$ & $45 \%$ & $65 \%$ & $5 \%$ \\
Cut-off $>28$ & $15 \%$ & $89 \%$ & $5 \%$ \\
\hline
\end{tabular}

${ }^{\star}$ Positive predictive value.

pregnant women in their study, sensitivity of the algorithm was low-only $38 \%$ when examination variables were included, but with a high specificity ( $76 \%)$. When we used a cut-off of 8 , as for prostitutes in their study, sensitivity improved but specificity was substantially lowered; positive predictive value was around 5\% in all combinations. In order to estimate the potential impact of our lack of data on chlamydia, we estimated the effect on positive predictive value, assuming a prevalence of chlamydia of $5 \%$, as in the Vuylsteke ${ }^{15}$ study. When we assumed that the sensitivities and specificities of a combined algorithm for chlamydia and gonorrhoea (from table 3) were similar to those for the algorithm for gonorrhoea alone, positive predictive value improved to a maximum of $13 \%$ (data not shown).

\section{Discussion}

The risk factors studied varied in importance between the different STDs. Although some trends emerged for all STDs, such as positive associations with variables relating to sexual behaviour, other risk factors varied between STDs and in some cases showed associations in opposite directions. Education was not consistently associated with the STDs studied, as higher education was inversely associated with trichomoniasis, but positively associated with gonorrhoea and candida. In addition, a woman's occupation was also not consistently predictive of risk. These differences between STDs may be due to the presence of different core groups for STD transmission, ${ }^{16}$ or a variety of complex behavioural, biologic and ecologic factors, potentially including STD treatment, that influence the rate of spread and distribution of STDs. ${ }^{17}$

We observed several associations between contraceptive use and STDs. An inverse association of OC use with risk of trichomoniasis has also been reported in other studies. ${ }^{181920}$ Few studies have examined the association between IUD use and lower genital tract infections. $^{21} 22$ In our study, IUD users were at increased risk of trichomoniasis and syphilis; there may be a biological explanation, such as facilitation of infection by mechanical means, or this may be a chance finding or confounding by unmeasured factors. A positive association of trichomoniasis with current IUD use was also found in a similar study in Nairobi, ${ }^{18}$ but these findings require further confirmation.
Condom use has been shown to provide good protection against most STDs for men, but the data for women are equivocal..$^{23}$ Rosenberg et $\mathrm{al}^{24}$ found that users of condoms had a reduced risk of gonorrhoea and trichomoniasis in a US population, but few studies have reported a protective effect for STDs in $\mathbb{D}$ African women where the prevalence of con- $\overrightarrow{0}$. dom use is generally very low. ${ }^{1125}$ Although there was a suggestion of an inverse association of regular condom use with most STDs in our study, the number of regular condom users was too small to draw conclusions.

We observed several significant associations? between the different STDs, and also between $\frac{\bar{F}}{\bar{N}}$ STDs and candidiasis. As previously reported $\frac{\bar{s}}{\sigma}$ by Kapiga et al, ${ }^{11} \mathrm{HIV}$ in this population was $\cong$ associated with other STDs, a finding consis-ळ tent with other studies. A possible explanation $\vec{\circ}$ for the strong inverse association of candidiasis $\overrightarrow{-}$ and gonorrhoea is that antibiotic treatment for vaginal discharge may increase risk of candidi- $\stackrel{\infty}{=}$ asis, although we did not have data on recent $\omega$ treatment of STDs to directly assess this issue.Candidiasis was not associated with any of the $\omega$ known STD risk factors in our data. The asso-음 ciations between different STDs, emphasisesthe importance of considering combined treat - T ment even if a woman is diagnosed with only? one STD.

There are several limitations of cross sectional designs in studying STD transmission. Ideally, incidence of STDs should be studied. within a cohort study with data on STD treat-o ment, but such studies are difficult and expensive to perform especially in settings whereo follow up is problematic. Prevalence of STDs, $\frac{\circ}{\mathbb{Q}}$ the measure of disease frequency used in cross $\Rightarrow$ sectional studies, is a proxy for true incidence $\frac{3}{3}$ and depends on a number of factors including the availability of treatment. In addition, the temporal nature of associations cannot bew determined. Furthermore, as many variables were examined for each outcome, some find $-\frac{3}{3}$ ings may be due to chance, and associationsô inconsistent with prior hypotheses should be interpreted carefully.

The sensitivity and positive predictive value of combinations of signs and symptoms in the diagnosis of individual STDs was generallyo low, but specificity remained high. Positiven predictive value (PPV) of any screening test is ${ }_{\omega}^{N}$ directly proportional to the prevalence of theo STD being screened for, suggesting that algo-e rithms with high PPV in high prevalence set-币 tings such as STD clinics will have a lowerPPV in more general population based settings such as family planning clinics. An important limiting factor in our study in assessing perfor- $\frac{\pi}{\Phi}$ mance of these algorithms is that screening for $C$ trachomatis was not performed. If women infected with $C$ trachomatis have the same risko profiles as the other STDs, then our estimates of PPV will be lower than if we had been able to include chlamydia as an outcome. Indeed, when we examined the performance of the algorithm of Vuylsteke et $a l^{15}$ under the assumption of a prevalence of chlamydia of $5 \%$, PPV improved moderately but remained low. Because of the relatively high number of 
false positives from the gonorrhoea algorithm, PPV will remain low, even if chlamydia were determined with perfect algorithm sensitivity. Thus if we had data on chlamydia, we would expect the algorithm to perform only moderately better than our estimate, dependent on the age-specific prevalence of chlamydia in the population.

The use of STD algorithms, based on clinical signs and symptoms for symptomatic women has been advocated for use in developing countries by the World Health Organisation (WHO). ${ }^{26}$ Such algorithms were used recently in a randomised trial of STD treatment in Tanzania which demonstrated that the diagnosis and treatment of STDs substantially reduced HIV incidence. ${ }^{27}$ However, these algorithms have been shown to have relatively low sensitivity and specificity when tested in both high and low prevalence populations. ${ }^{15} 1828$ Algorithms which use scoring systems, based on coefficients from logistic models, show an improved sensitivity and specificity over list-based systems. ${ }^{15}$ In our study, the maximum sensitivity reached using this method was around $80 \%$, but at the expense of low specificity, which would result in the unnecessary treatment of potentially large numbers of women detected as false positives. These observations reinforce the continuing need for inexpensive field tests to diagnose specific STDs and improvement of clinical diagnostic algorithms to reduce the impact of STDs and HIV in developing countries.

This study received financial support from the Rockefeller Foundation through the AIDS and Reproductive Health Network. D $M$ Gertig is a Harkness Fellow of the Commonwealth Fund of New York. During the design phase of the study, S H Kapiga was supported by a training gran from the Fogarty International Center, National Institutes of Health (D43 TW 00002) to the Harvard AIDS Institute.

We are grateful to the following people for participation in data collection and laboratory analyses: C Chuma, I Ballonzi, data collection and laboratory analyses: C Chuma, I Ballonzi, also thank the Tanzanian Ministry of Health for allowing us to also thank the Tanzanian Ministry of Health for allowing us to
conduct this study in the Family Planning Clinics in Dar-esSalaam.

1 De Schryver A, Meheus A. Epidemiology of sexually transmitted diseases: the global picture. Bull World Health Organ 1990;68:639-54.

2 Brunham RC, Embree JE. Sexually transmitted diseases current and future dimensions of the problem in the third world. In: Germain A, Holmes KK, Piot P, Wasserhei JN, eds. Reproductive Tract Infections: Global Impact and Priorities for Women's Reproductive Health. New York: Plenum Press 1992.

3 Mosha F, Nicoll A, Barongo L, Borgdorff M, Newell J, Senkoro $\mathrm{K}$, et al. A population-based study of syphilis and sexually transmitted disease syndromes in northand sexually transmitted disease syndromes in northwestern Tanzania. 1. Prevalen
4 Mabey DC, Lloyd-Evans NE, Conteh S, Forsey T Sexually transmitted diseases among randomly selected attenders at an antenatal clinic in The Gambia. $\mathrm{Br} \mathcal{F}$ Venereal Dis 1984;60:331-6.

5 Laga M, Nzila N, Goeman J. The interrelationship of sexually transmitted diseases and HIV infection: implications for the control of both epidemics in Africa. AIDS 1991; 5:S55-S63.

6 Pepin J, Plummer FA, Brunham RC, Piot P, Cameron DW, Ronald AR. The interaction of HIV infection and other sexually transmitted diseases: an opportunity for other sexually transmitted dise

7 Mertens TE, Hayes RJ, Smith PG. Epidemiological methods to study the interaction between HIV infection and other sexually transmitted diseases. AIDS 1990;4:57-65.

8 Piot P, Laga M. Genital ulcers, other sexually transmitted diseases, and the sexual transmission of HIV. BMF 1989, 298:623-4.

9 Wasserheit JN. Epidemiological synergy. Interrelationships between Human Immunodeficiency Virus infection and other sexually transmitted diseases. Sex Transm Dis 1992; 19:61-77.

10 Braddick MR, Nadinya-Achola JO, Mirza NB, Plummer FA, Irungu G, Sinei SK, et al. Cofactors in male-female transmission of HIV-1. F Infect Dis 1991;163:233-9.

11 Kapiga SH, Shao JF, Lwihula GK, Hunter DJ. Risk factors for HIV infection among women in Dar-es-Salaam, Tanzania. $\mathcal{F}$ Acquir Immune Defic Syndr 1994;7:301-9.

12 SPSS/PC + V4.0, SPSSInc, Chicago, Illinois, USA.

13 Hosmer DW, Lemeshow S. Applied Logistic Regression. Wiley \& Sons, Inc., 1989;43-44.

14 Rosner B. Fundamentals of Biostatistics. Boston: PWS-Kent, 1990;171-3.

15 Vuylsteke B, Laga M, Alary M, Gerniers M-M, Lebughe J$\mathrm{P}, \mathrm{Nzila} \mathrm{N}$, et al. Clinical algorithms for the screening of women for gonococcal and chlamydial infection: evaluation of pregnant women and prostitutes in Zaire. Clinica Infectious Diseases 1993;17:82-8.

16 Yorke AY, Hethcote HW, Nold A. Dynamics and contro of the transmission of gonorrhoea. Sex Transm Dis 1987 5:51-6.

17 Holmes KK. Human ecology and behavior and sexually transmitted bacterial infections. Proc Nat Acad Sciences 1994;91:2448-55.

18 Costello Daly C, Maggwa JK, Mati JK, Solomon M, Mbugua S, Tukei PM, et al. Risk factors for gonorrhoea, Mbugua S, Tukei PM, et al. Risk factors for gonorrhoea,
syphilis, and trichomonas infections among women syphilis, and trichomonas infections among women attending family planning clinic
Genitourin Med 1994;70:155-61.

19 Holmes KK, Mardh P-A, Sparling PF, Wiesner PJ Sexually transmitted diseases. McGraw-Hill Book Company, New York.

20 Bramley M, Kinghorn G. Do oral contraceptives inhibit Trichomonas vaginalis? Sex Transm Dis 1979;6:261-3.

21 Cates W, Stone K. Family planning, sexually transmitted diseases and contraceptive choice: a literature updatepart II. Fam Plann Perspect 1992;24:122-8.

22 Roy S. Nonbarrier contraceptives and vaginitis and vaginosis. Am $\mathcal{F}$ Obstet Gynecol 1991;165:1240-4.

23 Cates W, Stone K. Family planning, sexually transmitted diseases and contraceptive choice: a literature updatePart I. Fam Plann Perspect 1992;24:75-84.

24 Rosenberg MJ, Davidson AJ, Chen J-H, Judson FN, Douglas JM. Barrier contraceptives and sexually transmitted diseases in women: a comparison of femaledependent methods and condoms. Am $\mathcal{f}$ Public Health 1992;82:669-74.

25 Kapiga SH, Lwihula GK, Shao JF, Hunter DJ. Predictor of AIDS knowledge, condom use and high-risk sexual behaviour among women in use and high-risk sexual behaviour among women in Dar-

26 World Health Organization. Management of patients with sexually transmitted diseases. World Health Organ Tech Rep Ser 1991:810

27 Grosskurth H, Mosha F, Todd J, Mwijarubi E, Klokke A Senboro $\mathrm{K}$, et al. Impact of improved treatment of sexually transmitted diseases on HIV infection in rural Tanzania: randomised controlled trial. Lancet 1995;346:530-6.

28 Braddick MR, Ndinya-Achola JA, Mirza NB, Plumme FA, Irungu G, Sinei KA, Piot P. Towards developing a diagnostic algorithm for Chlamydia Trachomatis and Neisseria gonorrhoeae cervicitis in pregnancy. Genitourin Med 1990;66:62-5. 